\title{
A Propósito da Revisão das Diretrizes sobre Lombalgias e Lombociatalgias e a Propriedade de Dar Nome a Achados Relevantes
}

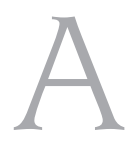

s queixas relacionadas a problemas de coluna vertebral, principalmente da região lombar, constituem motivo de consultas cotidianas e freqüentes. O reumatologista, enquanto médico clínico do aparelho locomotor, necessita manter-se permanentemente atualizado e alerta, cumprindo seu papel para que se concretize um bom diagnóstico e um tratamento adequado, evitando conseqüências que vão desde dificuldades para simples atividades da vida diária até problemas no trabalho, com seqüelas econômicas e sociais. Não são raros os pacientes que recorrem ao reumatologista, após um ou mais episódios que levaram a uma, talvez bem intencionada, mas equivocada intervenção cirúrgica. As espondiloartropatias soro-negativas são um exemplo bem conhecido dessa verdade.

É com muita satisfação, portanto, que, em Suplemento Especial de nossa Revista Brasileira de Reumatologia, apresentamos o texto das Diretrizes sobre Lombalgias e Lombociatalgias, organizado sob a coordenação do professor Hamid Alexandre Cecin e que conta com a opinião segura de representantes de especialidades que contribuem para o melhor entendimento e conduta na presença desses problemas. A todos o nosso agradecimento.

Mas eu não poderia deixar passar a oportunidade, uma obrigação até, para atentar a um detalhe peculiar e histórico. Há no bojo dessas Diretrizes, mais precisamente na Diretriz II, em Diagnóstico Clínico - Exame Físico, a descrição de um assim denominado, sinal X. Esse sinal, uma conjugação simultânea da flexão da coluna lombar com a manobra de Valsalva, citado aí, já fora apresentado no XXI Congresso
Brasileiro de Reumatologia, em 1996, e, em um estudo a ser publicado, em 66 pacientes com lombociatalgia aguda, apresenta uma prevalência de positividade de $95,5 \%$ nas hérnias discais agudas (22 confirmadas pela tomografia axial computadorizada e 44 pela ressonância magnética). $\mathrm{O}$ sinal de Làsegue, na mesma amostra, foi positivo em $81,9 \%$. Em trabalho experimental publicado em 1999, autores estrangeiros (Wilke HJ, Peter Neef, Caimi M, Hoogland $\mathrm{T}$, Claes LE. New In vivo measurements of pressures in the intervertebral disc in daily life. Spine. 1999;24(8):755-62), comprovaram os fundamentos biomecânicos do sinal.

$\mathrm{O}$ sinal $\mathrm{X}$, nada mais é do que uma descoberta baseada na observação clínica de um experiente colega, o professor Hamid Alexandre Cecin, responsável pela organização dessa revisão de Diretrizes e por muitos outros trabalhos dedicados ao ensino da reumatologia em nosso país. Com representatividade circunstancial, enquanto presidente da Sociedade Brasileira de Reumatologia, mas a perene convicção de que contribuições dessa natureza devem ser valorizadas por sua importância ao conhecimento da arte médica, sugiro que passe a ser denominado, a partir dessa publicação, como "Sinal de Cecin". Estou convicto de que um gesto como esse não tem valor de decreto, nem a intenção de premiar vaidades, apenas o reconhecimento do mérito de um brasileiro, como nós.

Um grande abraço a todos,

Fernando Neubarth Presidente da Sociedade Brasileira de Reumatologia 